\title{
Challenges for the EU Climate Change Regime
}

\author{
Liz Fisher*
}

\section{A. Introduction}

For those wanting to get an overview of the European Union's (EU's) climate change regime, a good place to start is the European Commission's climate action webpages. ${ }^{1}$ The website sets out the different actions and initiatives that the $\mathrm{EU}$ is taking in relation to climate change. There is a page on the benefits of climate action and another page on the results from a 2017 survey showing the public supports such action. There are also quizzes for kids and adults. They test climate change knowledge and in particular the aspirations of EU climate change policy. For example, one question asks: "By how much has the EU committed to cut its greenhouse gas emissions by 2020 ?" 2 The answer is $20 \%$.

This focus on aspirations in the quiz is not surprising. The center piece of this website is a series of ambitious targets. For 2030, these are: At least $40 \%$ cut in greenhouse gas emissions compared with 1990; at least 32\% of total energy consumption from renewable energy; and at least 32.5\% increase in energy efficiency. As is obvious from the quiz question, these are not the only targets on the website. Targets are also included in directives, ${ }^{3}$ and related targets can be found in the Paris Agreement ${ }^{4}$ and national legislation. ${ }^{5}$

\section{B. Challenges: Linear and Non-Linear}

In reading these pages and doing the quizzes, it is tempting to see the "challenge" in relation to climate change for the 2020s as primarily about implementing and achieving these targets. At the very least, the EU needs to meet the legal obligations it has set for itself. Ideally it needs to go even further. This linear direction of travel appears mapped out. The important thing is not to deviate from it.

This linearity is misleading, however. ${ }^{6}$ The many causes and consequences of climate change do not make it a problem solved in this way. ${ }^{7}$ As the late Ursula le Guin also put it: "Changing our minds is going to be a big change. To use the world well, to be able to stop wasting it, and our time

\footnotetext{
${ }^{\star}$ Professor of Environmental Law, Faculty of Law and Corpus Christi College, University of Oxford. Thanks to Sanja Bogojevic for comments on an earlier version on this Article.

${ }^{1}$ EU Climate Action, EUr. Commission, https://ec.europa.eu/clima/citizens/eu_en (last visited Sep. 9, 2019).

${ }^{2}$ EU Climate Action Quiz, Eur. Commission, https://ec.europa.eu/clima/sites/quiz/index.html.

${ }^{3}$ Directive 2009/28, of the European Parliament and of the Council of 23 April 2009 on the Promotion of the Use of Energy from Renewable Sources and Amending and Subsequently Repealing Directives 2001/77/EC and 2003/30/EC, 2009 O.J. (L 140) 16 .

${ }^{4}$ Paris Agreement art. 2, Dec. 12, 2015, T.I.A.S. No. 16-1104.

${ }^{5}$ Climate Change Act 2008, c. 27, $₫ 1$ (Eng.).

${ }^{6}$ Amitav Ghosh, The Great Derangement: Climate Change and the Unthinkable (2016).

${ }^{7}$ Elinor Ostrom, Polycentric Systems for Coping with Collective Action and Global Environmental Change, 20 GLOBAL ENVTL. ChANGE 550 (2010).
}

(c) The Author(s) 2020. Published by Cambridge University Press on behalf of the German Law Journal. This is an Open Access article, distributed under the terms of the Creative Commons Attribution-NonCommercial licence (http://creativecommons.org/licenses/by-nc/4.0/), which permits unrestricted re-use, distribution, and reproduction in any medium, provided the original work is properly cited. 
in it, we need to relearn our being in it." 8 Climate change requires dramatic relearning in the shift to low carbon economies. As the Intergovernmental Panel on Climate Change recently noted:

Pathways limiting global warming to $1.5^{\circ} \mathrm{C}$ with no or limited overshoot would require rapid and far-reaching transitions in energy, land, urban and infrastructure (including transport and buildings), and industrial systems .... These systems transitions are unprecedented in terms of scale, but not necessarily in terms of speed, and imply deep emissions reductions in all sectors, a wide portfolio of mitigation options and a significant upscaling of investments in those options. ${ }^{9}$

There is a target, but working towards it requires holistic and wide-ranging thinking about markets, regulation, infrastructure, and much else.

The EU leads the world in thinking imaginatively about these issues. It and its Member States have built an impressive architecture that is multi-level and polycentric in nature. While there is no room to detail it here, it has developed a rich set of legal and other initiatives across a range of different sectors. It has done so on the firm foundations of the internal market and its longstanding commitment to environmental protection. The end result is a regime that requires all the institutional, legal, and constitutional infrastructures of the EU and its Member States to work. Courts, legislatures, and administrators at multiple levels are involved, as are a range of other public and private actors. The regime has involved the co-production of markets and state authority ${ }^{10}$ and extensive dispute resolution. ${ }^{11}$ It has also catalyzed new initiatives among public and private actors both inside and outside the EU. ${ }^{12}$

All this needs to be maintained, strengthened, and added to in the transition to a sustainable future. Cases such as Urgenda ${ }^{13}$ and Carvalho ${ }^{14}$ underscore that there are powerful arguments that EU and Member States' actions need to be more ambitious. These arguments, however, do not detract from the fact the EU climate regime is a complex institutional phenomenon that takes the necessity of responding to climate change in a collective way seriously. The danger with headlining targets misrepresents this institutional and legal reality.

\section{Challenges: Output and Input Legitimacy}

Downplaying the institutional resources involved in responding to climate change also misconstrues what a "challenge" is. The Oxford English Dictionary defines a challenge as "[a] calling in question or disputing; the state of being called in question." 15 A challenge is "an act of calling to account." It is not just the completion of a pre-ordained task. It is about legitimacy.

Thinking of challenge in these terms raises tricky questions for the EU climate regime about what it means to "call it into question." From an "output legitimacy" perspective, ${ }^{16}$ one could argue that the climate change targets are the outputs, and so working towards those targets holds the EU to account. The problem is whether the EU has actually met this challenge or not, and the answer

\footnotetext{
${ }^{8}$ Ursula Le Guin, Deep in Admiration, in Arts of Living on a Damaged Planet (Anna L. Tsing et al. eds., 2017).

${ }^{9}$ Special Report: Global Warming of 1.5': Summary for Policy Makers 17, International Panel on Climate Change (2018).

${ }^{10}$ Sanja Bogojevic, Emission Trading Schemes: Markets, States and Law (2013).

${ }^{11} I d$.

${ }^{12}$ E.g., Michèle Finck, Above and Below the Surface: The Status of Sub-National Authorities in EU Climate Change Regulation, 26 J. ENVTL. L. 443 (2014).

${ }^{13}$ See The Urgenda Climate Case Against the Dutch Government, URGENDA, https://www.urgenda.nl/en/themas/climatecase/ (last visited Sep. 6 2019) (indicating that this litigation is ongoing).

${ }^{14}$ See ECJ, Case T-330/18, Carvalho v. Parliament and Council, ECLI:EU:T:2019:324, Order of 8 May 2019 (currently on appeal).

${ }^{15}$ Challenge, OXFord English Dictionary (2019).

${ }^{16}$ Fritz Scharpf, Governing in Europe: EfFective And Democratic? (2011).
} 
will only become obvious at a future point in time. Given the global collective action problem of climate change, meeting the target does not mean serious climate change is adverted. Overall, focusing on targets in regards to climate change is a less than ideal form of output legitimacy.

The other classic way of thinking about the accountability and legitimacy of the EU is in terms of "input legitimacy," that is, democracy. ${ }^{17}$ Given that much of the EU climate change regime involves the national and sub-national legislative architectures of Member States, it does not suffer from the "democratic deficits" of areas such as EU monetary policy. ${ }^{18}$ Thus, it might be tempting to see little in the way of challenges when it comes to input legitimacy.

But democracy is an "essentially contested concept."19 As the political struggles in many Member States attest, we live in times when right-wing populism is reshaping understandings of democracy. Populism is not easy to define..$^{20}$ At its core, it is the mobilization of "the people" to express a political will against what is characterized as a group of "elites." Inherent in such mobilization is a strong desire to override or bypass existing governing institutions and practices in the name of democracy. While populism is also evoking a future utopia-often one grounded in a romanticized past-it is also about the "power of the moment." ${ }^{21}$ By connecting the people with a ruler, the hope is that an immediate political transformation will take place.

As a recent report notes, right wing populist parties in EU member states eschew strong climate change policies seeing climate change as a liberal-elitist concept. ${ }^{22}$ Climate change policies "are perceived as expensive, unjust, harmful to the environment or not worthwhile." 23 This stance is bolstered by what the authors of the report call "four overarching and cross-cutting frames:" "economic decline," "homeland ("Heimat") and nature," "national independence", and "scientific dissent." ${ }^{24}$ In regards to the last of these, the report notes that one third of these political parties are skeptical of the science of climate change, and most of the rest are disengaged from it. ${ }^{25}$

None of this is surprising. ${ }^{26}$ Addressing climate change requires changing present patterns of behavior in quite radical ways. This is economically and socially disruptive. It requires transforming infrastructure, ways of doing business, and how people go about living their lives. For communities that are feeling in an already precarious position, action in regards to climate change can make them feel even more precarious. The paradigm example of this is the gilets jaunes (yellow vests) protests against fuel levy hikes in France. ${ }^{27}$

Furthermore, while climate change action reflects democratic wishes, it also requires governing institutions to operate. It is not about the direct relationship between the ruler and the people. It is not about the immediacy of the moment.

\section{Meeting Challenges}

Populism thus presents the most serious legitimacy challenge for the 2020s. The current depiction of climate change action on the European Commission's climate action website does not

\footnotetext{
${ }^{17} I d$.

${ }^{18}$ Ignacio Sánchez-Cuenca, From a Deficit of Democracy to a Technocratic Order: The Postcrisis Debate on Europe, 20 ANN. Rev. Pol. SCI. 351 (2017).

${ }^{19}$ W.B. Gallie, Essentially Contest Concepts, 56 Proc. Aristotelian Soc’y 156 (1955).

${ }^{20}$ For some overviews, see Jan Werner Müller, What is Populism? (2016); The Oxford Handbook of Populism (Cristóbal R. Kaltwasser et al. eds., 2017).

${ }^{21}$ Samuel Issacharoff, Populism versus Democratic Governance, in CONSTITUTIONAL DEMOCRACY IN CRISIs? 445, 449 (Mark Graber et al. eds., 2018).

${ }^{22}$ Stella Schaller \& Alexander Carius, Convenient Truths: Mapping Climate Agendas of Right-Wing Populist PARTIES IN EUROPE 42 (2019).

${ }^{23}$ SCHARPF, supra note 16 .

${ }^{24}$ SCHARPF, supra note 16 .

${ }^{25}$ Finck, supra note 12 .

${ }^{26}$ Elizabeth Fisher, Unearthing the Relationship Between Populism and Environmental Law, 31 J. ENVTL. L. (2019).

${ }^{27}$ Jeremy Harding, Among the Gilets Jaunes, 41(6) LONDON REv. Books 3 (2019).
} 
assist in meeting that challenge. Presenting climate change as requiring a linear direction of travel towards a set of targets gives little room for the voicing of the concerns and anxieties of those drawn to populism. It is a narrative of smooth transition, not jarring disruption. A narrative of protecting the future, not managing the present. A narrative of hard-edged targets, not keenly-felt powerlessness. The website talks of the "green jobs" that could be created, cleaner transport, and smart buildings, but very little of what is involved in creating all these different things.

Overall, it reinforces the idea that climate change is an elitist project because there is little in the way of the experience of people in moving towards these targets. To put the matter another way, it reinforces populist disenchantment. What emerges is a vicious circle of mutual political frustration. All the while, the problem of climate change is not going to go away.

The irony is that, as noted above, the website is misleading. It makes invisible the genuine successes of the EU and the Member States. Doing the quiz gives no feeling for how the EU's emissions trading scheme has been crafted through a series of phases ${ }^{28}$ or how Member State courts have managed the disruption of energy transitions. ${ }^{29}$ It is also the case that populism need not necessarily be anti-climate change. The gilets jaunes have stated they are not anti-climate change action, but that any action needs to take into account social justice concerns. ${ }^{30}$

This is not to say that the EU's targets are wrong and should be abandoned. My point is that the "challenges" of climate change are not really about meeting those targets. They are challenges about how we assess the legitimacy and accountability of institutions in a process where we "relearn our being in the world." 31

That also highlights how understandings of the EU's legitimacy are not really fit for purpose. The focus, as seen above, has been on output and input legitimacy. But ensuring that the challenges of climate change are met requires focusing on "through-put" legitimacy. It requires a focus on how disruption is managed as fairly as possible, on how disputes are resolved, and on how consensus is built. It requires an appreciation that responding to climate change involves all the intellectual resources of governing-it requires us to dig deep so as to understand the nuance of the multi-level polity of the EU and its processes as well as its history and its tensions. It requires us to understand the commitment of that polity to modes of public reason and dispute resolution. In meeting the challenges of climate change, we need to take the institutional structures seriously. They need to be made visible in all their complexity.

That visibility is important for another reason. As populism highlights, we also need to think about the narratives we tell about governing. Those narratives are part of deeper stories ${ }^{32}$ — stories that help us make sense of ourselves as citizens and the EU as an institution that governs us. The appeal of populism is that it often evokes nostalgia for a past. Retreating to that past is particularly appealing when faced with uncertain physical and economic futures. We should also not underestimate the difficulties in fostering different, deeper stories. Making visible the processes and nuances of governing aids in that process of relearning. It is not a magic wand, but then again, when it comes to the challenges of climate change, there are none of those.

A final note: The quizzes on the Commission's website bother me. My teenage sons and I took them. They both muttered frustrations at being asked questions about targets and about what an energy label can show. They rolled their eyes. They got annoyed at not doing very well.

\footnotetext{
${ }^{28}$ Sanja Bogojevic, Trading Schemes, in OxFORD HANDBOOK COMPARATIVE ENVTL. LAW 926 (Jorge Viñuales \& Emma Lees eds., 2019).

${ }^{29}$ Elizabeth Fisher, Law and Energy Transitions: Wind Turbines and Planning Law in the UK, 38 OXFORD J. LEGAL STUD. 528 (2018).

${ }^{30}$ Emily Atkin, France's Yellow Vest Protesters Want to Fight Climate Change, New RePublic (Dec. 10, 2018), https:// newrepublic.com/article/152585/frances-yellow-vest-protesters-want-fight-climate-change.

${ }^{31}$ LE GUIN, supra note 8.

${ }^{32}$ Arlie R. Hochschild, Strangers in their own Land: Anger and Mourning on the American Right (2016).
} 
The problem of course is that such a quiz makes the process of relearning appear a shallow, not a deep process. It narrows the field of vision to specific strategies. It ignores the bigger governance question. In meeting the challenges of the 2020s in relation to climate change, I suggest not just making the architecture of climate change governance more visible, ${ }^{33}$ but also to lose the quizzes.

\footnotetext{
${ }^{33}$ See also Bruno Latour, Down to Earth: Politics in the New Climactic Regime (2018).
}

Cite this article: Fisher L (2020). Challenges for the EU Climate Change Regime. German Law Journal 21, 5-9. https://doi.org/ $10.1017 /$ glj.2019.87 